\title{
Design Priority Service Using Intelligent Communication Technology on Railways Payment
}

\author{
Muhammad Ashar \\ Teknik Informatika Jurusan Tekenik Elektro \\ Fakultas Teknik Universitas Negeri Malang \\ J1. Senarang 5 Malang, Jawa Timur 65145, Indonesia \\ e-mail: muhammad.ashar.ft@um.ac.id
}

\begin{abstract}
The development of digital automatization system by synergizing intelligent communication technology (ICT) with various Indonesian railway user applications needed to be addressed digitally and integrated through Mobile Touch innovation to provide intelligent solutions reliably, safely, efficiently and comfortably environmentally Trains in Indonesia. The use of Mobile Touch Technology in various mobile applications is the focus of research by utilizing media such as smartphones, smartcards and smartwacth in online digital services that can be applied to features developed with Ubiquitous Computing framework in every railway area. KaiTo+ apps were designed to challenge and improve customer numbers and the effectiveness of digital service automation system utilization such as Multi Trip Cards, Multi Function Cards, Time Schedule, Pre-Order, Mobile WiFi, Digital payment, And Realtime Ticketing Systems. They were expected to provide simultaneous and synergistic service simultaneously on transportation interconnection system, payment, and other online information access.
\end{abstract}

Keywords: Intelligent Communication, Mobile Touch, Ubiquitous, Mobile Apps, Railways

\section{INTRODUCTION}

Information technology based on digital applications has been implemented by PT.Kereta Api Indonesia since 2009. This effort is made to provide innovative services to users of rail services in Indonesia in the form of digital services. One of these technology services is Application Utilization technology that has been implemented in commuter line by applying eticketing and e-gate on railway restoration service. For restaurant service. In addition, this service can be equipped to pamper customers with pre order service that is pre order menu ordering system that is on the ticket sales website Train [1].

The use of RTS (Rail Ticketing System) as a digital ticket application online has a huge impact in order to provide services to train customers easily. This application proved able to provide solutions to increase the number of customers and provide profits for the corporation PT.KAI very significant in the year 2016 with total revenues reached 20 trillion rupiahs or increased by $48.18 \%$ (68.54 million people) from the previous year. With this RTS PT.KAI sure will surge in the number 72.3 million people or an increase of 13.5 trillion rupiahs [2].

Evaluation of RTS application (2012) demonstrates the efficient use of operational cost and service convenience for passengers by reducing the queue at the ticket counter and seat number in accordance with printed boarding so as to reduce the overcrowded seats due to uncontrolled and integrated ticket sales.

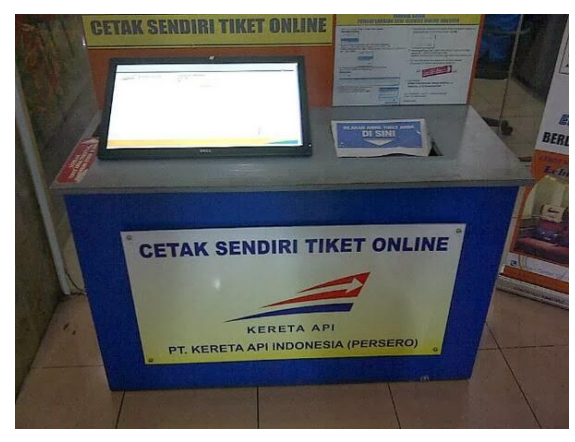

Fig 1 ATM ticketing for online service system (semaker.com)

RTS application system with the ease of prospective passengers can order and get ticket purchase through the web and online systemsuch as through service of PT Pos Indonesia, Contact Center 121, drive thru, vending machine, mobile phone, mobile ticketing or market kiosk.

The development of mobile touch system on RTS is an innovative service in facilitating railway customers by using digital payment media such as smartcard, smartphone, smartwatch through system integration of service products 
such as Electronic Ticketing (as used on Jabodetabek commuter), Boarding System Manifest, Check Seat Passanger, Customer service application (subscription ticket for employee or pns), pre order application in ordering product or requirement in online statiun area, host to hos service with ease of access service integrated with online transport, rail schedule and order and payment ticketing by call 24 hours. Currently RTS tyrunan applications have been well developed by several KAI subsidiaries such as KCJ, PT KAI Tourism, PT Reska Multi Usaha, PT KAI Logistics, PT Railink, and PT KAI Property Management and others.

The positive impact of the use of digitalization system and IT products in KAI can save costs around Rp 25 billion with the addition of working capital of Rp. 140 Millar per year. This potential is very interesting if RTS application is developed continuously by utilizing ubiquitous system technology called RTSplus in order to provide customer care solutions and profit products.

When the use of card-based RTS has been using Touch Screen technology, bluetooth, NFS, WiFi access, and even DTN is used in various countries with advanced technology railway transportation system and adequate service management. As well as Malaysia and Singapore who have utilized the Touch and Go Card system via railway cards in one card portal to make payment access and apps, an additional ation for customers around the use of modern trains. While the online payment service systemhas been widely used with other media not only for cards but also can directly use our smartphone. such as mobile touch that is applied to smartphone-based mobile ticket for railroad customers in New York. [3] While touching in and out with smartwacth has been used by the state of India for railway ticket payments known as lack watcth2pay in collaboration with delhi corporations metro rail. [4].

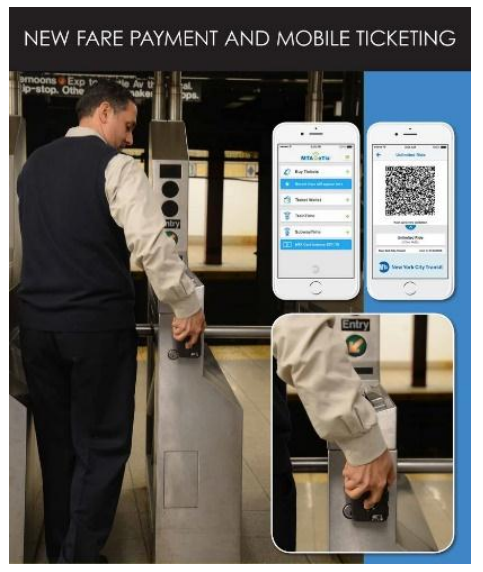

Fig 2. Mobile Touch Technology on the train

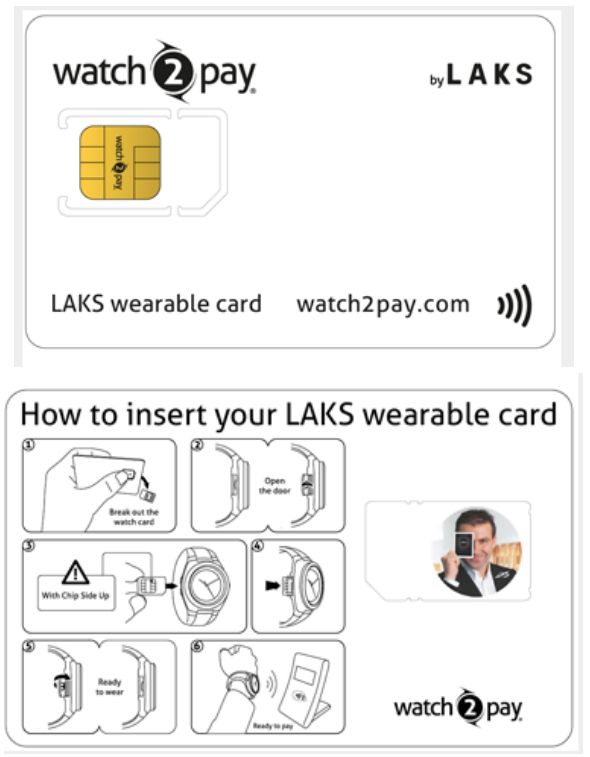

Fig 3. Mobile payment touch embedded on Smartwatch

Assuming RTS plus media and technology supporters can adopt as previously described technologies to be developed into RTS service innovation and technology in Indonesia to create new service products in KAI system in the form of commercialization of latest technology products so as to provide opportunities for developing mobile applications for national independence especially the development of railway transportation automation Indonesia with IT digitization system.

Currently the concept of mobile-based payment system or the use of mobile devices (mobile devices) developed in 2 categories namely;

1, NFC (Near Field Communication) where using mobilephone NFC tools that act as a payment card (contactless payment card) through the payment of mobile account by debit from the owner's bank account (debit or credit card)

2. mPOS (Mobile point-of-solution) where payment application (mobile payment apps) is downloaded into mobilephone to perform the function as a terminal point of sale and card reader (secure card reader).

The two mobile devices and payment systems mentioned above are popular in a number of countries and can be seen in the following table: 
TABLE 1.

CITY USING SMARTPHONE FOR T HE FARE PAYMENT

\begin{tabular}{|c|c|}
\hline Fare Media & CITIES \\
\hline MPOS & $\begin{array}{l}\text { Bucharest, Cardiff, Copenhagen, Dallas, Edinburg, } \\
\text { Frankfurt, Helsinki,London, Madrid,Milan, Moscow, } \\
\text { Munich, Narobi, Osjek,Prague, Stockholm, Szczecin, } \\
\text { Vienna, Zagreb }\end{array}$ \\
\hline$N F C$ & $\begin{array}{l}\text { Bangkok, Beijing, Boston, Bucharest, Caen, Chicago, } \\
\text { Dubai, Florence, Frankfurt, Guanzhou, Hongkong, } \\
\text { Kualalumpur, Moscow, Nairobi, new Jersey, Novosibirsk, } \\
\text { Osjek, Oslo, Portland, Singapore, starbourg, } \\
\text { Tokyo,,Wellington, }\end{array}$ \\
\hline
\end{tabular}

Source : Global Mass transit Research

Furthermore, ticket delivery schemes using the smartphone network via message transmission (text message) can be done online with the form of SMS tickets or barcode tickets. Through this technology rail users can easily purchase and pay for tickets on a mobile basis by reading barcode scans (can also QR code) and get information and transaction amounts of payments that can be done on autodebet or online transfer.

So some advantages of using mobile payment application on RTS or train plus service are: (1). Does not involve the cost of making the card, (2). User friendly and easy to carry without risk of missing or defective card, (3) .Ability to integrate with real-time passenger information system, onboard Wi-Fi and other services, (4). High mobile and service charge for passengers

While losses arising from this system are (1). Views are limited by the size of the mobile display screen, (2) .Promotion compromise in security, (3) .Battery low and / or no network availability may hamper ticket purchases or the ability to validate tickets; (4). more expensive and less powerful than smart card readers

The goal of innovative mobile app innovation development research is to get easy, secure and secure integration system in conducting online payment transaction for railway user needs in synergy with media and gadget technology owned by customers. In addition, the study on the prospect of multifunctional service innovation with mobile touch technology can be run in accordance with the conditions and infrastructure of a communications network in the statiun area in improving the performance of the system more optimally and efficiently by integrating each other.

The expected output target of KaiTo + application is to build the parototype and payment service system with mobile touch through 3 alternative media ie smartcard, NFC, and Smartwatch by considering the effectiveness of connection and influence of media usage on user accessibility in accordance with service feature priority.

\section{METHOD}

The experimental descriptive research method is designed to experiment and test on system reliability that has been designed through the framework of the system which is divided into 3 stages: Touch Card, NFC Mobile Touch, Touch Touch through the design of wifi and mobile internet based communication service. Analysis of experimental results using statistical techniques in determining the optimization of services or systemproducts such as access speed, effectiveness and service priority, and system performance. Continue collection and processing of data and aspects of the following product and system analysis:

\section{A. Data Collection Method}

Data obtained from a number of service activities related to an online payment system for KAI service users.

\section{B. Data Processing}

Data processing using the approach method quantitatively by providing check list. The results of data conducted in a direct survey with the online media compared with the results of trials in a number of statiun that have implemented the same system and mobile touch technology in a number of locations and cities and other countries.

\section{C.Data Analysis}

The results of system experiments conducted data analys is with 6 aspects carried this:

1. Service system performance

2. Network ommunication problem

3. Application Design and Userfriendly

4. Trend of Technology and Life

5. Trust and Security

6. Supporting Funding

The system feasibility and validation of test results are visualized in graphical form as processed data to be a reference in making priority services. A review of aspects of sustainability and future system development in the decisionmaking process for the implementation system needs to be added by adding enggineering social engineering analysis with the market analysis in accordance with the big data application system at KaiTo + .

\section{System \& Product Design}

Product design is made by making a simple prototype with specifications in accordance with the needs of small diarea such as rail station with consideration of ease of access and service Kaito + can work optimally with the data service network system. 
Further development of product engineering and physical service systems from KaiTo + is made to produce applications that are ready to be implemented with wide coverage to be used as a railroad user application operating in the city area. The design of hardware systems and application software is made user friendly with the feasibility of the mobile web based / front end back / end for smartwach and smartphone users. Furthermore, the ease of the database system in querying information related to the identification of input, process, and output data payment is stable and accurate without high delay and interfensi.

\section{E. Implementation}

The product application process in use in rail area is done by the parallel system and redudance in every terminal (box) of service of KaiTo + application. Gradually the system implementation begins on the systemoutside the statiun area to the stage of implemntasi on the area of statiun, and in the railway with the assumption of internet network interconnection system has been established both from the system by PT. KAI as well as on the user's mobile device system.

\section{F. Framework System}

KaiTO + media and service is designed as a means of payment on the Railway system in Indonesia for integrated passenger services with applications with mobile services and websites. Ease of access is available in 3 media ie NFC enabled payment card, Smartvard payment, and NFC enabled wristwatches [6] which can be used through touch reading system where contacless payment machine is placed in station form at some point in railway station area.Selanjutnaya KaiTo + systemcan process the desired output by kerete customers to make payment transactions through applications made with web or mobile models. In the payment application will support redicRTS system, PreOrder, Transport Interconection, and others. This application also supports debit and creditcard through the button selection menu on the application page set on android phone [7]

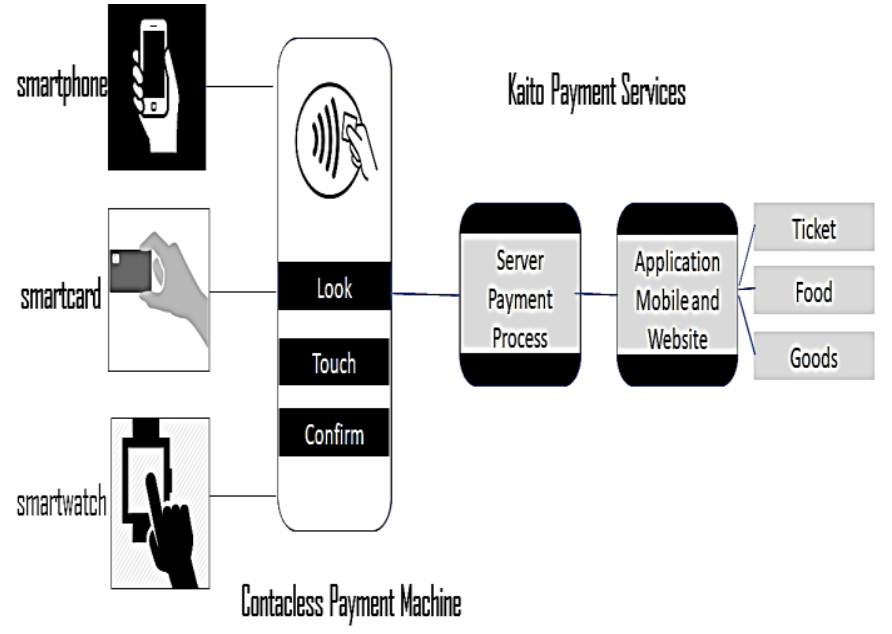

Fig 4. Overview KaiTo+ Mobile Touch Apps

\section{PERFORMANCE AND DISCUSSION}

The appearance of service quality is measured according to the age of the users towards the feasibility of the mobile touch systemto be applied to the payment system in the railway station area in big cities in order to increase the convenience and access the user needs. Of the 3 media that synergize in one integrated mobile touch system as optional media used as payment tools can compare the quality of services and applications that provide the most comfort in the four levels of user age. Measurements show that smartwatch as a mobile touch medium for service and access to rail has $90 \%$ service quality for users (tenageer). While the use of smartphones as a service access for children is the smallest that is only $40 \%$. For services with smartcards between $80-90 \%$ many provide optimal service quality for tenageer and adult. All three media provide services that almost have the same quality and are widely used in adults.

Service quality certainly measures the speed of access, ease of access, secure and computer networks that support both wifi network and mobile internet usage. As a reference system of mobile portal usage to improve railway information system services can be applied to provide ease of customer access for applications will run and active with sourced mobile server distribution [8]. The development of integrated systems with KaiTO + can work together to keep the stability of access to applications on KaiTo + with mobile touch.

Railpay for various transactions In addition, the development of a multifunction card as a tool trnasaski with various kemudahaan that can be accessed when and manapun.Sistem can be integrated with KaiTo + application based on smartcard [9] 


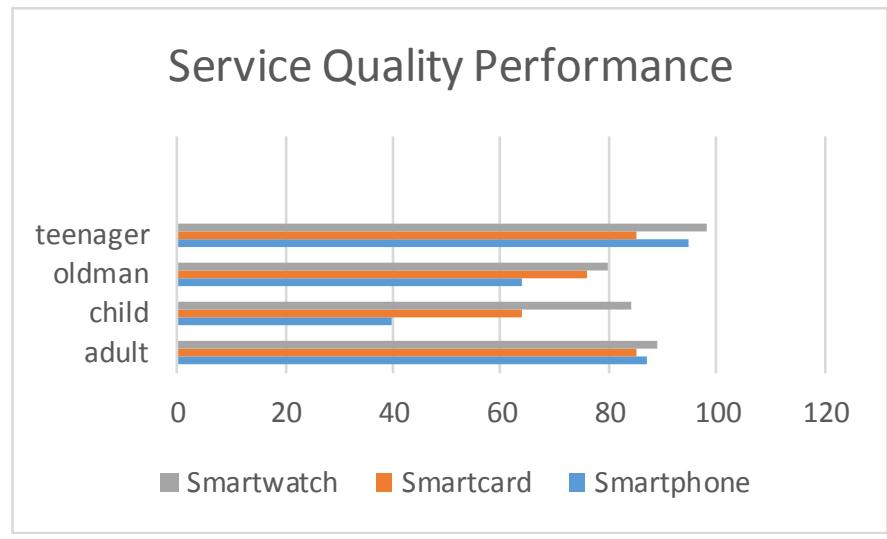

Fig 5. Prosentase of service quality performance mobile touch

The measurement of the user's interest system for the smart touch or mobile touch media in sequence for children, teenager, adults, and oldman has an enthusiastic response rate of $72 \%, 89 \%$

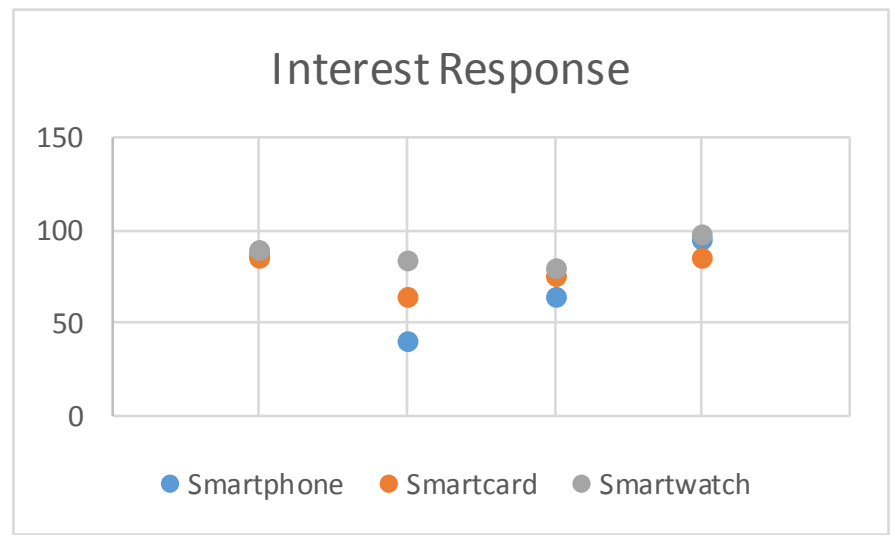

Fig 6. Distribution of application user group tested by KaiTo+ apps

Implementation constraints and costing mechanisms in terms of policies and strategies to realize the mobile touch system applied to the payment system in KAI can be given a solution by adding product ads from the existing info system access diarea

\section{CONCLUSION}

Mobile touch with the synergy of various media access for payment system can be used optimally and meet user response specially adult class worthy of being tested competence in railstation. From the result of measurement of service quality given at 4 age level show the highest media value of service quality that is smartwatch

\section{REFERENCES}

[1] http://www.beritasatu.com/ekonomi/388690-pt-kereta-api-jajakiteknologi-layanan-digital.html

[2] https://www.goodnewsfromindonesia.id/xhr/render/article/sainsteknologi/kembangkan-industri-ict-indonesia-11-mahasiswa-inimagang-di-ajou-university-korea-selatan/1468310512/5

[3] You won't be able to use your phone to pay for an NYC subway ride until 2021,https://www.theverge.com/2016/4/12/11416362/mta-nycfare-payment-contactless-mobile-ticketing

[4] https://watch2pay.com/ watch2pay with recharable has partnered with delhi metro rail ticket

[5] Smartphone applications in transit services: Growing popularity [free access] http://www.globalmasstransit.net/archive.php?id=16210, May 2014

[6] http://www.t3me.com/en/news/events-expos/gitex-technology-week2015/you-can-soon-pay-dubai-metro-fares-using-smartwatch

[8] http://www.androidauthority.com/uber-android-pay-discount-715317/

[9] https://www.itb.ac.id/news/read/3063/home/optimalkan-kenyamananpenumpang-kereta-api-dengan-mobile-portal

[10] Https://Infokomputer.Grid.Id/2016/12/Berita/Berita-Reguler/Pt-KeretaApi-Kartu-Railpay-Bayar-Transportasi 